\title{
Screening for Type 2 Diabetes in Adults: An Updated Systematic Review ${ }^{\S}$
}

\author{
Diana Sherifali ${ }^{1}$, Donna Fitzpatrick-Lewis ${ }^{*, 2}$, Leslea Peirson $^{2}$, Donna Ciliska $^{1,2}$, Doug Coyle $^{3}$ \\ ${ }^{1}$ Faculty of Health Sciences, McMaster University, Hamilton, Ontario, Canada \\ ${ }^{2}$ McMaster Evidence Review and Synthesis Centre, (MERSC), Hamilton, Ontario, Canada \\ ${ }^{3}$ Faculty of Medicine, University of Ottawa, Ottawa, Ontario, Canada
}

\begin{abstract}
Background: This review was conducted to determine the clinical benefit and potential harms of screening for type 2 diabetes mellitus (T2DM) in asymptomatic adults.

Methods: The search strategy from the 2008 US Preventive Services Task Force's framework on type 2 diabetes screening was updated. MEDLINE ${ }^{\circledR}$ and the Cochrane Database of Systematic Reviews were searched from 2007 to 2012 for systematic reviews, randomized controlled trials and modeling studies. Study quality was assessed using the GRADE System and a standardized review process.

Results: Previous results showing benefit of screening among those with high blood pressure were confirmed. No new or old trials were found regarding the effect of screening for T2DM on mortality, cardiovascular mortality and diabetes related complication outcomes. An observational study demonstrated a modest benefit in mortality in an initial cohort invited for T2DM screening (1990-1992), (HR 0.79; 95\% CI 0.63, 1.00), but was not replicated in the second cohort invited for screening (2000-2003). Modeling studies reported that population based screening in high-risk individuals (age and hypertension as risk factors) might increase quality adjusted life years and was cost-effective if screening began at age 45 and every three to five years thereafter. Two new randomized controlled trials noted that screening was associated with higher levels of short-term anxiety and worry, but had limited overall psychological impact.

Interpretation: This review found no controlled studies of the effectiveness of screening for T2DM, and one observational study demonstrating a modest benefit on mortality. Evidence for the harms associated with screening showed minimal clinical significance. Differences between current and previous evidence can be attributed to the current methodology that integrates the GRADE approach. Recommendations for screening reflect the best available evidence and include screening individuals at high risk for T2DM every 3-5 years with an A1C test, and individuals at very high risk annually with an $\mathrm{A} 1 \mathrm{C}$ test.
\end{abstract}

Keywords: Screening, type 2 diabetes, systematic review.

\section{INTRODUCTION}

In 2006-2007, there were an estimated 211,168 new cases of diabetes diagnosed in Canada, with the prevalence of diagnosed diabetes for the whole population at $6.2 \%[1,2]$ In 2008-2009, the national prevalence of diagnosed diabetes rose to $6.8 \%$ [2]. As diabetes diagnosis is often delayed, 20$50 \%$ of people with type 2 diabetes mellitus (T2DM) present with complications at the time of diagnosis and experience mortality rates at least two times higher than those without diabetes [2-5]. The 2005 Canadian Task Force recommendations suggest screening for T2DM in: a) adults with hypertension; and b) hyperlipidemia, to prevent cardiovascular events and death [6]. Similarly, the 2008 United States

Address correspondence to this author at the McMaster Evidence Review and Synthesis Centre (MERSC), 1685 Main Street West, Suite 302, Hamilton, Ontario, L8S 1G5, Canada; Tel: 905-525-9140, 20471; Fax: 905529-4184; E-mail: fitzd@mcmaster.ca

${ }^{\S}$ Note: This paper is based on a full report "Screening for Type 2 Diabetes in Adults", which can be found at: http://canadiantaskforce.ca/wpcontent/uploa ds/2012/10/Diabetes_Screening_06182012FINAL.pdf
Preventive Services Task Force (USPSTF) recommendations suggest screening asymptomatic adults with treated or untreated blood pressure greater than $135 / 80 \mathrm{~mm} \mathrm{Hg}$ [7] (Table 1). Additional guidelines from the World Health Organization [8] and the American Association of Diabetes [9] suggest screening for T2DM should be considered in those with risk factors for diabetes (e.g. hypertension, hyperlipidemia, related cardiovascular disease, obesity, history of GDM), commencing at the age of 45 years and repeated in 3 year intervals [9].

A review was completed to update the 2005 Canadian Task Force on Preventive Health Care (CTFPHC) guidelines on screening for T2DM and the evidence review of the 2008 USPSTF [6,7]. The goal of the review was to determine the clinical benefit of screening for T2DM using fasting plasma glucose (FPG), oral glucose tolerance test (OGTT), or a glycated hemoglobin (A1C) in asymptomatic adults, 18 years of age or older, at high risk for diabetes complications; and to determine the harms associated with screening for T2DM using, FPG, OGTT, or A1C in the same population.

The USPSTF questions and analytic framework were used to guide this review [7]. The key questions for the review included: 
Table 1. Characteristics of Included Study for Key Question 1: Clinical Benefits of Screening for Type 2 Diabetes

\begin{tabular}{|c|c|}
\hline First Author & Simmons, RK [17] \\
\hline Country & UK \\
\hline Title of Study & Effect of population screening for type 2 diabetes on mortality: long-term follow-up of the Ely cohort \\
\hline Objective & To assess the impact of invitation to screening for type 2 diabetes and related cardiovascular risk factors on population mortality \\
\hline Methods & $\begin{array}{l}\text { Design: Parallel-group population-based cohort } \\
\text { Selection: All adult patients, aged 40-65, free of known diabetes, registered with a single practice in Ely, UK }(n=4,936) \\
\text { Blinding: N/A }\end{array}$ \\
\hline Participants & $\begin{array}{l}\text { Sample: 1990-92: 1,705 randomly invited for screening; 1,157 (68\%) attended screening; 3,231 not invited for screening } \\
\quad \text { 2000-03: (of those not invited in 1990-92) 1,577 randomly invited for screening; } 714 \text { (45\%) attended; 1,425 never invited } \\
\text { Characteristics (of invited and not invited screening groups in 1990): } \\
\text { Sex: } 45.1 \% \text { male (invited); } 50.7 \% \text { male (not invited) } \\
\quad \text { Mean Age at Entry: } 52.8 \text { years (male and female invited); } 50.9 \text { years (male not invited) and } 51.2 \text { (female not invited) } \\
\text { Withdrawals/Drop-outs: N/A } \\
\text { Study Recruitment Years: } 1990-1992 \\
\text { Follow Up: up to } 18 \text { years }\end{array}$ \\
\hline Intervention & Invited for screening for type 2 diabetes or not invited; additional comparison of screening attenders versus non-attenders \\
\hline Outcomes & $\begin{array}{l}\text { Population mortality was assessed by flagging all individuals in the original sampling frame, including those not invited for screening, } \\
\text { for death certification at the Office of National Statistics. Vital status was obtained for the entire cohort and results for follow-up to } \\
\text { January 31, } 2008 \text { are reported. There were } 345 \text { deaths between } 1990 \text { and } 1999 \text { (median } 10 \text { year follow up). Adjusting for age, sex and } \\
\text { deprivation, individuals invited to the } 1990-1992 \text { screening had a non-significant, } 21 \% \text { lower, all-cause mortality (HR } 0.79 ; 95 \% \text { CI } \\
0.63-1.00 \text {; p. 05). There were } 291 \text { deaths between 2000-2008 (median } 8 \text { year follow-up), with no significant difference in mortality } \\
\text { between participants who were invited and not invited to the 2000-2003 screening. } \\
\text { Compared with the non-invited group, those who attended screening at any point had a significantly lower mortality and those who did } \\
\text { not attend had a significantly higher mortality. }\end{array}$ \\
\hline
\end{tabular}

1. What is the evidence for the clinical benefit of screening for T2DM using fasting plasma glucose, oral glucose tolerance test, or A1C in asymptomatic adults 18 years of age or older at high risk for diabetes complications to improve intermediate and final health outcomes?

2. What is the evidence for the harm of screening for T2DM using fasting plasma glucose, oral glucose tolerance test, or A1C in asymptomatic adults 18 years of age or older at high risk for diabetes complications?

For the evidence review, harm outcomes included depression and anxiety. Several contextual questions were added to the USPSTF framework and were in the full review. The contextual questions addressed issues relevant when considering screening adults forT2DM, such as patient values, risk factors to guide screening, benefits and harms to early treatment; and the effectiveness of risk factor tools or questionnaires to predict T2DM. The review also addressed the following contextual questions:

1. What are the most effective (accurate and reliable), risk assessment tools or questionnaires to predictT2DM?

2. What risk assessment tools or questionnaires to predict T2DM have been validated in Canada?

3. What is the yield (accuracy, reliability, prevalence, and feasibility) of screening for T2DM with FBG, OGTT, and A1C in adult patients?

The objective of this review is to update the evidence related to Key Question 1 of the USPTFS review; specifically, what is the evidence for the clinical benefit of screening for T2DM in high risk, asymptomatic adults 18 years of age or older. This review will report on the evidence for the harms of screening, as well as the evidence for contextual questions [3-5].

\section{METHODS}

The USPSTF searched MEDLINE ${ }^{\circledR}$ and the Cochrane Library for relevant English language systematic reviews, randomized controlled trials and observational studies published between March 2001 and July 2007, related to diabetes screening, and potential adverse effects. Clinical Trials.gov was also searched for relevant trials. To update the CTFPHC, the USPSTF search strategy was implemented, and all searches were updated from 2007 to February 2012. EMBASE was not searched, as it was not searched in the original USPSTF review. Reference lists of key articles were also reviewed. A grey literature search was also completed to find relevant Canadian data.

Eligible studies were in English or French and included asymptomatic adults 18 years or older at average or high risk for T2DM complications. Study designs for effectiveness of screening included randomized controlled trials or systematic reviews and meta-analyses and observational studies with mortality, cardiovascular mortality and diabetesrelated complications as outcomes. For harms and costeffectiveness, various study designs and multiple data sources were included. Titles and abstracts were reviewed in duplicate by members of the synthesis team; full text inclusion, quality assessment and data extraction were done by two people who resolved disagreements through discussions. Data were abstracted by two people using a standard format; 
in cases of disagreement, consensus was reached after consultation with a third reviewer. For studies related to contextual questions, abstraction was done by one person.

Individual study quality was assessed as well as overall level of evidence. Study quality was based on the risk of bias due to limitations in design, inconsistency of findings, indirectness, imprecision and publication bias. The strength and quality of evidence was determined based on the GRADE system, using GRADEPro software [10-12]. We abstracted data about the patient population, the study design, analysis and results for each study. Reviews were quality assessed using the AMSTAR tool [13].

The CTFPHC procedural manual allows for the use modeling studies when there is insufficient evidence to answer some or all of the key questions [14]. The Diabetes Screening Working Group determined that there was insufficient evidence to adequately answer components of the effectiveness question particularly regarding age cohorts, intervals and high risk groups requiring screening. A separate search for modeling studies and critical appraisal of the evidence followed the CTFPHC procedure manual and evidence-based tools $[14,15]$. Briefly, the appraisal of modeling studies adopted a five-step process which involves assessment based on both applicability to the research question and study quality. The review process is described in detail in the full evidence review and synthesis report [16].

\section{RESULTS}

Our search located 11,456 potentially relevant citations (Fig. 1). Of these, title and abstract screening excluded 8,$947 ; 2,340$ papers were retrieved and assessed on inclusion criteria. Three studies met the criteria for the key questions: one new cohort study for mortality [17]; and two studies for harm [18, 19]. For study characteristics, risk of bias and GRADE evidence related to mortality, please refer to Tables 2-4; for study characteristics, risk of bias and GRADE evidence related to harms, please refer to Tables 5-7.
No new randomized controlled trials or systematic reviews were identified answering key question 1 since the 2008 USPSTF Recommendation Statement for the Screening of Type 2 Diabetes [20]. The 2008 USPSTF retrieved only three relevant studies (one case-control and two crosssectional studies) and found no benefit from screening for microvascular complications or any good data for the effectiveness of screening for T2DM in any targeted population [7]. Similarly to the 2008 USPSTF, two modeling studies were included for this updated review [21, 22].

\section{Screening for T2DM- Mortality}

A population-based cohort study of 4,936 individuals examined the impact of early, delayed and no screening for T2DM using a $75 \mathrm{~g}$ OGTT and related cardiovascular (CV) risk factors on mortality [17]. All cause mortality was $21 \%$ lower in the cohort that participated in early screening versus not invited to screening (HR 0.79; 95\% CI 0.63-1.00); similarly mortality was lower in those with delayed screening (HR 0.52; 95\% CI 0.35-0.78) than those not invited to screening [17]. A study summary, risk of bias and GRADE evidence are found in Tables 2-4.

\section{Screening for T2DM - Modeled Studies}

The review identified two studies of high methodological quality [21,22]. In a UK study, screening appeared to be cost effective for the 40-70 year age cohort and most effective for hypertensive and obese individuals, as the costs of screening were offset by lower future treatment costs [21]. In a US study, the strategy of screening the entire population $\geq 30$ years of age every three years was the optimal strategy, assuming a decision maker was willing to pay at least $\$ 12,961$ per QALY [22]. However, if there were recognizable disutilties associated with labeling, the benefits of screening may be outweighed by potential harms the 30 to 45 year old age group. The major limitation of both studies was that they required assumptions relating to glucose control and treatment effectiveness in screened individuals rather than based on empirical data.

Table 2. Risk of Bias Table for Study Included for Key Question 1: Clinical Benefits of Screening for Type 2 Diabetes

\begin{tabular}{|c|c|c|}
\hline Item & Judgment & Description \\
\hline Adequate sequence generation? & No & $\begin{array}{l}\text { Observational (Parallel Cohort) Study. Participants were randomly selected (in two cohorts, } \\
1997-99 \text { and 2000-03) for invitation to screening from a single practice population. The authors } \\
\text { do not describe how patients were randomly selected to receive a screening invitation. }\end{array}$ \\
\hline Allocation concealment? & No & $\begin{array}{l}\text { Observational (Parallel Cohort) Study. No information about allocation concealment, probably } \\
\text { not done. }\end{array}$ \\
\hline Blinding? & No & $\begin{array}{l}\text { Observational (Parallel Cohort) Study. The authors do not discuss issues related to blinding. } \\
\text { Blinding of participants would not be possible in this study. The authors do not discuss blinding } \\
\text { of outcome assessors. Two researchers independently coded cause of death. If these researchers } \\
\text { were aware of a patient's status (screening versus no screening) it is possible this information } \\
\text { might influence their classification of cause of death. However, the mortality outcome would } \\
\text { not be affected by a lack of blinding. }\end{array}$ \\
\hline Incomplete outcome data addressed? & Yes & $\begin{array}{l}\text { Outcome (death) reported for all patients in sampling frame including those who were invited } \\
\text { to screening and attended, those who were invited and did not attend, and those who were not } \\
\text { invited }\end{array}$ \\
\hline Free of selective reporting? & Yes & All outcomes of interest were reported on in the results. \\
\hline Free of other bias? & Yes & No other biases were observed. \\
\hline
\end{tabular}


Table 3. GRADE Evidence Profile and Summary of Findings Table for Study Included for Key Question 1: Clinical Benefits of Screening for Type 2 Diabetes (Simmons et al. [17])

\begin{tabular}{|c|c|c|c|c|c|c|c|c|c|c|c|c|}
\hline \multirow{2}{*}{\multicolumn{7}{|c|}{ Quality Assessment }} & \multicolumn{5}{|c|}{ Summary of Findings } & \multirow{3}{*}{ Importance } \\
\hline & & & & & & & \multicolumn{2}{|c|}{ No of patients } & \multicolumn{2}{|r|}{ Effect } & \multirow[b]{2}{*}{ Quality } & \\
\hline $\begin{array}{c}\text { No of } \\
\text { Studies }\end{array}$ & Design & Limitations & Inconsistency & Indirectness & Imprecision & $\begin{array}{c}\text { Other } \\
\text { Considerations }\end{array}$ & Screening & Control & $\begin{array}{c}\text { Relative } \\
\text { (95\% } \\
\text { CI) }\end{array}$ & Absolute & & \\
\hline \multicolumn{13}{|c|}{ Overall Mortality (1990-1992 Cohort) (Follow-up Median 10 Years'; Death Certificate at Office of National Statistics) } \\
\hline \multicolumn{13}{|c|}{ Overall Mortality (2000-2003 Cohort) (Follow-up Median 8.1 Years'; Death Certificate at Office of National Statistics) } \\
\hline 1 & $\begin{array}{c}\text { observational } \\
\text { study }\end{array}$ & $\begin{array}{l}\text { no serious } \\
\text { limitations }\end{array}$ & $\begin{array}{c}\text { no serious } \\
\text { inconsistency }^{3}\end{array}$ & $\begin{array}{c}\text { no serious } \\
\text { indirectness }\end{array}$ & $\begin{array}{l}\text { no serious } \\
\text { imprecision }\end{array}$ & none $^{3}$ & $\begin{array}{l}165 / 1,577 \\
(10.46 \%)\end{array}$ & $\begin{array}{c}126 / 1,425 \\
(8.84 \%)\end{array}$ & $\begin{array}{c}\text { HR } 1.18 \\
(0.93 \\
\text { to } \\
1.51)^{6,9}\end{array}$ & $\begin{array}{c}15,065 \text { more per } \\
1,000,000 \text { (from } \\
5,927 \text { fewer to } \\
42,039 \text { more) }\end{array}$ & $\begin{array}{l}\oplus \oplus \Theta \Theta \\
\text { LOW }\end{array}$ & CRITICAL \\
\hline
\end{tabular}

${ }^{1} 1991$ to 1999 (47,854 person-years of risk).

${ }^{2}$ The authors report potential selection bias: "despite random selection of participants into invitation groups, participants who were offered screening were older at baseline, lived in more deprived areas and included a smaller proportion of men." However, we did not downgrade this criterion since in the analysis the researchers adjusted for age, sex and deprivation.

${ }^{3}$ Single study.

${ }^{4} 52(45 \%)$ of deaths were recorded as cancer-related, 41 (35\%) were due to cardiovascular causes and 23 (20\%) were coded as 'other'.

${ }^{5} 107(47 \%)$ were cancer deaths, $74(32 \%)$ were cardiovascular deaths and $48(21 \%)$ were coded as 'other'.

${ }^{6} \mathrm{p}=0.05$; adjusted for age, sex and deprivation.

${ }^{7}$ For 22 individuals (6\%) among the total deceased (1991-1999), diabetes was included as the underlying cause on the death certificate.

${ }^{8} 2000$ to $2008(23,144$ person-years of risk).

${ }^{9}$ For 22 individuals (8\%) among the total deceased (2000-2008) diabetes as included as the underlying cause on the death certificate.

Table 3. (Cont'd): GRADE Evidence Profile and Summary of Findings (Simmons et al. [17])

Summary of Findings Table for KQ1: Clinical Benefits of Screening for Type 2 Diabetes

\begin{tabular}{|c|c|c|c|c|c|}
\hline \multirow{3}{*}{ Outcomes } & \multicolumn{2}{|c|}{ Illustrative Comparative Risks* (95\% CI) } & \multirow{3}{*}{$\begin{array}{l}\text { Relative Effect } \\
\quad(95 \% \text { CI })\end{array}$} & \multirow{3}{*}{$\begin{array}{c}\text { No of } \\
\text { Participants } \\
\text { (Studies) }\end{array}$} & \multirow{3}{*}{$\begin{array}{l}\text { Quality of the } \\
\text { Evidence } \\
\text { (GRADE) }\end{array}$} \\
\hline & Assumed Risk & Corresponding Risk & & & \\
\hline & Control & Screening & & & \\
\hline $\begin{array}{l}\text { Overall Mortality (1990-1992 Cohort) } \\
\text { Death Certificate at Office of National } \\
\text { Statistics } \\
\text { Follow-up: median } 10 \text { years }\end{array}$ & 70,876 per $1,000,000^{2}$ & $\begin{array}{c}\mathbf{5 6 , 5 2 1} \text { per } \mathbf{1 , 0 0 0 , 0 0 0} \\
(45,337 \text { to } 71,000)^{3}\end{array}$ & $\begin{array}{c}\text { HR 0.79 } \\
(0.63 \text { to } 1)^{4,5}\end{array}$ & $\begin{array}{c}4,936 \\
\text { (1 study) }\end{array}$ & $\begin{array}{l}\oplus \oplus \Theta \ominus \\
\text { low }^{6,7}\end{array}$ \\
\hline $\begin{array}{l}\text { Overall Mortality (2000-2003 Cohort) } \\
\text { Death Certificate at Office of National } \\
\text { Statistics } \\
\text { Follow-up: median } 8.1 \text { years }^{8}\end{array}$ & 88,421 per $1,000,000$ & $\begin{array}{c}\mathbf{1 0 2 , 9 9 7} \text { per } \mathbf{1 , 0 0 0 , 0 0 0} \\
(82,100 \text { to } 129,854)\end{array}$ & $\begin{array}{c}\text { HR 1.18 } \\
(0.93 \text { to } 1.51)^{4,9}\end{array}$ & $\begin{array}{l}3,002 \\
(1 \text { study })\end{array}$ & $\begin{array}{c}\oplus \oplus \Theta \ominus \\
\text { low }^{7}\end{array}$ \\
\hline
\end{tabular}

*The basis for the assumed risk (e.g. the median control group risk across studies) is provided in footnotes. The corresponding risk (and its $95 \%$ confidence interval) is based on the assumed risk in the comparison group and the relative effect of the intervention (and its 95\% CI).

CI: Confidence interval; HR: Hazard ratio;

GRADE Working Group grades of evidence

High quality: Further research is very unlikely to change our confidence in the estimate of effect.

Moderate quality: Further research is likely to have an important impact on our confidence in the estimate of effect and may change the estimate.

Low quality: Further research is very likely to have an important impact on our confidence in the estimate of effect and is likely to change the estimate.

Very low quality: We are very uncertain about the estimate.

${ }^{1} 1991$ to 1999 (47,854 person-years of risk)

${ }^{2} 107(47 \%)$ were cancer deaths, $74(32 \%)$ were cardiovascular deaths and $48(21 \%)$ were coded as 'other'.

${ }^{3} 52(45 \%)$ of deaths were recorded as cancer-related, $41(35 \%)$ were due to cardiovascular causes and 23 (20\%) were coded as 'other'.

${ }^{4} \mathrm{p}=0.05$; adjusted for age, sex and deprivation.

${ }^{5}$ For 22 individuals (6\%) among the total deceased (1991-1999), diabetes was included as the underlying cause on the death certificate.

${ }^{6}$ The authors report potential selection bias: "despite random selection of participants into invitation groups, participants who were offered screening were older at baseline, lived in more deprived areas and included a smaller proportion of men." However, we did not downgrade this criterion since in the analysis the researchers adjusted for age, sex and deprivation.

${ }^{7}$ Single study.

${ }^{8} 2000$ to $2008(23,144$ person-years of risk)

${ }^{9}$ For 22 individuals (8\%) among the total deceased (2000-2008) diabetes as included as the underlying cause on the death certificate. 
Table 4. Characteristics of Included Studies for Key Question 2: Harms Related to Screening for Type 2 Diabetes

\begin{tabular}{|c|c|}
\hline First Author & Eborall, HC [18] \\
\hline Country & United Kingdom \\
\hline Title of Study & $\begin{array}{l}\text { Psychological impact of screening for type } 2 \text { diabetes: controlled trial and comparative study embedded in the ADDITION (Cambridge) } \\
\text { randomized controlled trial }\end{array}$ \\
\hline Objective & To quantify the psychological impact of primary care-based stepwise screening for type 2 diabetes. \\
\hline Methods & $\begin{array}{l}\text { Design: Randomized controlled clinical trial } \\
\text { Selection: Participants recruited from clinical settings that did not have diagnosed type } 2 \text { diabetes. } \\
\text { Blinding: Unclear }\end{array}$ \\
\hline Participants & $\begin{array}{l}\text { Sample: Invited for Screening ( } \mathrm{n}=6,416) \text {; Screened }(\mathrm{n}=4,370) \text {; Control }(\mathrm{n}=964) \\
\text { Characteristics: } \\
\text { Sex: } 35 \% \text { female (screened) and } 36 \% \text { female (control) } \\
\quad \text { Mean Age: } 58 \text { years (screened) and } 59 \text { years (control) } \\
\text { Withdrawals/Drop-outs: N/A } \\
\text { Study Recruitment Years: N/A } \\
\text { Follow Up: up to } 15 \text { months }\end{array}$ \\
\hline Intervention & Invited for screening for type 2 diabetes or not invited (controls); comparative study of subgroups of screening attendees \\
\hline Outcomes & $\begin{array}{l}\text { Anxiety was measured using the Spielberger State Anxiety Inventory (STAI) (short form); anxiety and depression were measured using } \\
\text { the Hospital Anxiety and Depression Scale (HADS); diabetes-specific worry was measured using the adapted Lerman Cancer Worry } \\
\text { Scale (LCWS). } \\
\text { No significant differences at baseline, } 3-6 \text { months and } 12-15 \text { months between the type } 2 \text { diabetes screened group (random plasma glucose } \\
\text { screening) and the controls in any outcomes. } \\
\text { Screening had a limited psychological impact on patients, with some negligible negative psychological impact with subsequent clinical } \\
\text { investigations following a positive screen test for type } 2 \text { diabetes. }\end{array}$ \\
\hline
\end{tabular}

Table 4 (cont'd). Characteristics of Included Studies for Key Question 2: Harms Related to Screening for Type 2 Diabetes

\begin{tabular}{|c|c|}
\hline First Author & Park, P [19] \\
\hline Country & United Kingdom \\
\hline Title of Study & $\begin{array}{l}\text { Screening for type } 2 \text { diabetes is feasible, acceptable, but associated with increased short-term anxiety: A randomized controlled trial in } \\
\text { British general practice }\end{array}$ \\
\hline Objective & $\begin{array}{l}\text { To examine: a) the feasibility of a stepwise screening program in general practice; b) the uptake of the screening program; and c) the } \\
\text { effects of the program on participants' anxiety, self-rated health and illness perceptions of diabetes. A pilot study for the ADDITION } \\
\text { Cambridge study. }\end{array}$ \\
\hline Methods & $\begin{array}{l}\text { Design: Randomized controlled trial, randomized 2:1. } \\
\text { Selection: High risk participants were recruited from two general practices into a stepwise screening program to confirm the presence or } \\
\text { absence of diabetes. } \\
\text { Blinding: Unclear }\end{array}$ \\
\hline Participants & $\begin{array}{l}\text { Sample: Invited for Screening: Intervention }(\mathrm{n}=116) \\
\text { Not Invited for Screening: Control }(\mathrm{n}=238) \\
\text { Characteristics: } \\
\text { Sex: } 34 \% \text { female (intervention); } 37 \% \text { female (control) } \\
\text { Mean Age: } 58 \text { years (intervention); } 59 \text { years (control) } \\
\text { Withdrawals/Drop-outs: } 95 \text { (82\%) people attended the random capillary glucose test of the } 116 \text { that were invited. } \\
\text { Follow Up: } 6 \text { weeks }\end{array}$ \\
\hline Intervention & $\begin{array}{l}\text { Intervention: a letter invitation to attend screening for type } 2 \text { diabetes at their local general practitioner. } \\
\text { Control: no invitation to attend. }\end{array}$ \\
\hline Outcomes & $\begin{array}{l}\text { Anxiety was measured using the Spielberger State Anxiety Inventory (STAI) and illness perceptions were assessed using the } 50 \text {-item } \\
\text { diabetes Illness Perception Questionnaire (IPQ). } \\
\text { The intervention group followed a stepwise screening program including: a) a random capillary glucose test; b) a fasting capillary glucose test if } \\
\text { their random glucose test was } \geq 5.5 \mathrm{mmol} / \mathrm{L} ; \mathrm{c} \text { ) an oral glucose tolerance test if their fasting capillary glucose test was between } 5.5-12 \mathrm{mmol} / \mathrm{L} \text {. If } \\
\text { participants had a } 2 \text {-hour capillary glucose level } \geq 11.0 \mathrm{mmol} / \mathrm{L} \text {, they were informed they had type } 2 \text { diabetes. } \\
\text { Six weeks after participating, screen invited participants reported being more anxious than those not invited (mean STAI score: } 37.6 \mathrm{vs} \\
34.1, \mathrm{p}=0.015 \text { ) and those diagnosed with diabetes were more anxious than those determined to not have type } 2 \text { diabetes (mean STAI } \\
\text { score: } 46.7 \mathrm{vs} 37.0, \mathrm{p}=0.031 \text { ). } \\
\text { Screening for type } 2 \text { diabetes in the primary care setting is feasible but may be associated with higher levels of short-term anxiety in the } \\
\text { screen invited participants. }\end{array}$ \\
\hline
\end{tabular}


Table 5. Risk of Bias for Studies Included for Key Question 2: Harms of Screening for Type 2 Diabetes

\begin{tabular}{|c|c|c|}
\hline Item & Judgement & Description (Eborall, et al., 2007) [18] \\
\hline $\begin{array}{l}\text { Adequate sequence } \\
\text { generation? }\end{array}$ & No & $\begin{array}{l}\text { In the ADDITION (Cambridge) trial practices were randomly allocated to screening or control arms. In this sub- } \\
\text { study on the psychological impact of screening it was not possible to randomly select practices for screening } \\
\text { because it started later than the main trial and many practices had already finished screening. Furthermore, three of } \\
\text { the } 10 \text { screening sites included in this sub-study had already started the screening process. Therefore, } \\
\text { randomization was not deemed adequate for the sub-study. }\end{array}$ \\
\hline Blinding? & Unclear & $\begin{array}{l}\text { The authors do not discuss issues related to blinding. Blinding of practices and participants would not possible in } \\
\text { this study. The authors do not discuss blinding of outcome assessors. }\end{array}$ \\
\hline $\begin{array}{l}\text { Incomplete outcome } \\
\text { data addressed? }\end{array}$ & No & $\begin{array}{l}\text { There was loss to follow up among the invited to screening non-attenders. An analysis was done to assess the } \\
\text { impact if these non-responders had similar outcome measures at baseline. Non-response rates were similar across } \\
\text { the three main groups from the initial test to 3-6 months (roughly } 7 \% \text { ). }\end{array}$ \\
\hline Free of other bias? & Yes & No other biases were observed. \\
\hline Item & Judgement & Description (Park et al., 2008) [19] \\
\hline $\begin{array}{l}\text { Adequate sequence } \\
\text { generation? }\end{array}$ & Yes & $\begin{array}{l}\text { The investigators indicate they used SPSS (v.9.0.1) to individually randomize participants into invited and non- } \\
\text { invited groups. }\end{array}$ \\
\hline $\begin{array}{l}\text { Allocation } \\
\text { concealment? }\end{array}$ & Unclear & The authors do not discuss concealment of allocation. \\
\hline Blinding? & Unclear & The authors do not discuss issues related to blinding. \\
\hline
\end{tabular}

\section{Screening for T2DM - Harms}

The previous 2008 USPSTF identified eight observational studies that included heterogeneous populations and outcomes for harm, or which no serious adverse effects were noted [7]. The updated search identified two randomized controlled trials completed in the United Kingdom which reported on the adverse effects of screening for T2DM at the primary care level $[18,19]$. One study reported small but significant short term trends for negative self-reported health $(\mathrm{p}=0.047)$ and worry $(\mathrm{p}=0.001)$ [18]. A second pilot trial determined those invited for T2DM screening reported being more anxious than those not invited $(\mathrm{p}=0.015)$; and those diagnosed with diabetes were more anxious than those without T2DM $(\mathrm{p}=0.031)$ [19]. Both studies noted that screening for T2DM in the primary care setting is feasible, may be associated with higher levels of short-term anxiety, and had limited psychological impact $[18,19]$. Study summaries, risk of bias and GRADE evidence are found in Tables 5-7.

\section{Screening Risk Assessment Tools and Questionnaires}

The literature search identified a high quality systematic review that examined the most accurate and reliable risk assessment tools or questionnaires to predict T2DM (Table 8) [23]. Two additional papers were found validating the FINnish Diabetes RIsk SCore tool (FINDRISC) [24, 25]. The review specified seven validated score tools or models to be appropriate for clinical or public health settings: 1) FINDRISC; 2) Atherosclerosis Risk in Communities (ARIC); 3) Ausdrisk (Australia); 4) Cambridge risk score; 5) Framingham Offspring Study; 6) San Antonio risk score; and 7) QD Score [23]. The area under the receiver operating characteristic curve (AUROC) in the seven recommended tools ranged from 0.74 to 0.85 for internal validations and from 0.72 to 0.84 in external validations. Six out of the seven recommended tools have been validated internally and externally; Ausdrisk has not been externally validated and FINDRISC has been validated in the most countries (Finland, Holland, Denmark, Sweden, UK, Australia) [23]. The review also found preliminary data demonstrating a 
Table 6. GRADE Evidence Profile for Key Question 2: Harms Related to Screening for Type 2 Diabetes

\begin{tabular}{|c|c|c|c|c|c|}
\hline \multirow{2}{*}{ Outcomes } & \multirow{2}{*}{$\begin{array}{l}\text { No. of } \\
\text { Studies, } \\
\text { No. of } \\
\text { Patients }\end{array}$} & \multicolumn{2}{|c|}{ Mean Score (SD) } & \multirow{2}{*}{$\begin{array}{l}\text { Absolute Effect } \\
\text { (95\% CI), P Value }\end{array}$} & \multirow{2}{*}{ Quality Rating } \\
\hline & & No Invitation & Invitation & & \\
\hline \multicolumn{6}{|l|}{ ANXIETY } \\
\hline \multirow{2}{*}{$\begin{array}{l}\text { Spielberger State } \\
\text { Anxiety Inventory } \\
\text { (STAI) Park et al. } \\
2008[19]^{2,3-8}\end{array}$} & \multirow{2}{*}{$\begin{array}{l}1 \mathrm{RCT} \\
355 \\
\text { patients }\end{array}$} & \multicolumn{2}{|c|}{6 Weeks After Last Contact2 } & \multirow{2}{*}{$\begin{array}{l}\text { The mean STAI score in the } \\
\text { intervention group was } 3.5 \text { higher } \\
(0.22-6.78), 0.04\end{array}$} & \multirow{2}{*}{$\begin{array}{c}\oplus \oplus \oplus \ominus \\
\text { MODERATE } \\
\text { due to design } \\
\text { limitations } 3,4,5\end{array}$} \\
\hline & & $\begin{array}{l}34.1(12.1) \\
\mathrm{n}=168\end{array}$ & $\begin{array}{c}37.6(12.2) \\
\mathrm{n}=77\end{array}$ & & \\
\hline \multirow{6}{*}{$\begin{array}{l}\text { Spielberger State } \\
\text { Anxiety Inventory } \\
\text { (STAI) } \\
\text { Eborall et al. } 2007 \\
{[18]^{1,3-8}}\end{array}$} & \multirow{6}{*}{$\begin{array}{c}1 \mathrm{RCT} \\
7,380 \\
\text { patients }\end{array}$} & \multicolumn{2}{|c|}{ Initial Time Point6 } & \multirow{2}{*}{$\begin{array}{l}\text { The mean STAI score in the } \\
\text { intervention group was } 0.53 \text { lower } \\
(-2.60-1.54), 0.62\end{array}$} & \multirow{6}{*}{$\begin{array}{c}\oplus \oplus \Theta \ominus \\
\text { LOW } \\
\text { due to design } \\
\text { limitations } 3,4,5,7,8\end{array}$} \\
\hline & & $\begin{array}{c}32.7(11.5) \\
\mathrm{n}=199\end{array}$ & $\begin{array}{c}32.7(11.6) \\
\mathrm{n}=2,468\end{array}$ & & \\
\hline & & 3-6 Months Afte & l Time Point & The mean STAI score in the & \\
\hline & & $\begin{array}{c}31.8(11.4) \\
\mathrm{n}=358\end{array}$ & $\begin{array}{c}33.5(12.0) \\
\mathrm{n}=2,504\end{array}$ & $\begin{array}{l}\text { intervention group was } 1.51 \text { higher } \\
(-0.17-3.20), 0.10\end{array}$ & \\
\hline & & \multicolumn{2}{|c|}{ 12-15 Months After Initial Time Point } & \multirow{2}{*}{$\begin{array}{l}\text { The mean STAI score in the } \\
\text { intervention group was } 0.57 \text { higher } \\
(-1.11-2.24), 0.52\end{array}$} & \\
\hline & & $\begin{array}{c}32.8(11.8) \\
\mathrm{n}=304\end{array}$ & $\begin{array}{c}35.5(12.2) \\
\mathrm{n}=2,377\end{array}$ & & \\
\hline \multirow{6}{*}{$\begin{array}{c}\text { Hospital Anxiety } \\
\text { and Depression } \\
\text { Scale (HADS): } \\
\text { Anxiety Subscale } \\
\text { Eborall } \text { et al. } 2007 \\
\qquad 18]^{1,3-8}\end{array}$} & \multirow{6}{*}{$\begin{array}{c}1 \mathrm{RCT} \\
7,380 \\
\text { patients }\end{array}$} & \multicolumn{2}{|c|}{ Initial Time Point6 } & \multirow{2}{*}{$\begin{array}{c}\text { The mean HADS Anxiety score in } \\
\text { the intervention group was } 0.46 \\
\text { lower (-0.99-0.07), } 0.12\end{array}$} & \multirow{6}{*}{$\begin{array}{c}\oplus \oplus \Theta \Theta \\
\text { LOW } \\
\text { due to design } \\
\text { limitations } 3,4,5,7,8\end{array}$} \\
\hline & & $6.42(4.39) \mathrm{n}=255$ & $6.04(3.79) \mathrm{n}=3,140$ & & \\
\hline & & 3-6 Months Afte & l Time Point & The mean HADS Anxiety score in & \\
\hline & & $\begin{array}{c}5.97(3.86) \\
\mathrm{n}=442\end{array}$ & $5.91(3.89) \mathrm{n}=3,159$ & $\begin{array}{l}\text { the intervention group was } 0.12 \\
\text { lower }(-0.55-0.32), 0.61\end{array}$ & \\
\hline & & \multicolumn{2}{|c|}{ 12-15 Months After Initial Time Point } & \multirow{2}{*}{$\begin{array}{c}\text { The mean HADS Anxiety score in } \\
\text { the intervention group was } 0.01 \\
\text { lower }(-0.47-0.45), 0.98\end{array}$} & \\
\hline & & $5.81(3.87) \mathrm{n}=377$ & $5.85(3.87) \mathrm{n}=3,034$ & & \\
\hline \multicolumn{6}{|l|}{ DEPRESSION } \\
\hline \multirow{6}{*}{$\begin{array}{c}\text { Hospital Anxiety } \\
\text { and Depression } \\
\text { Scale (HADS): } \\
\text { Depression } \\
\text { Subscale } \\
\text { Eborall } \text { et al. } 2007 \\
{[18]^{1,3-8}}\end{array}$} & \multirow{6}{*}{$\begin{array}{c}1 \mathrm{RCT} \\
7,380 \text { patients }\end{array}$} & \multicolumn{2}{|c|}{ Initial Time Point6 } & \multirow{2}{*}{$\begin{array}{c}\text { The mean HADS Depression score } \\
\text { in the intervention group was } 0.37 \\
\text { lower }(-0.93-0.18), 0.21\end{array}$} & \multirow{6}{*}{$\begin{array}{c}\oplus \oplus \Theta \Theta \\
\text { LOW } \\
\text { due to design } \\
\text { limitations } 3,4,5,7,8\end{array}$} \\
\hline & & $\begin{array}{c}4.52(3.48) \\
\mathrm{n}=256\end{array}$ & $\begin{array}{c}4.24(3.31) \\
\mathrm{n}=3,161\end{array}$ & & \\
\hline & & \multicolumn{2}{|c|}{ 3-6 Months After Initial Time Point } & \multirow{2}{*}{$\begin{array}{c}\text { The mean HADS Depression score } \\
\text { in the intervention group was } 0.01 \\
\text { higher }(-0.51-0.54), 0.96\end{array}$} & \\
\hline & & $\begin{array}{c}4.18(3.38) \\
\mathrm{n}=444\end{array}$ & $\begin{array}{c}4.24(3.40) \\
\mathrm{n}=3,177\end{array}$ & & \\
\hline & & \multicolumn{2}{|c|}{ 12-15 Months After Initial Time Point } & & \\
\hline & & $\begin{array}{c}4.03(3.35) \\
\mathrm{n}=378\end{array}$ & $\begin{array}{c}4.28(3.40) \\
\mathrm{n}=3,049\end{array}$ & $\begin{array}{c}\text { in the intervention group was } 0.22 \\
\text { higher }(-0.31-0.74), 0.44\end{array}$ & \\
\hline
\end{tabular}

${ }^{1}$ Eborall et al used adjusted mean differences for age and comorbidity (use of antihypertensives) to compute absolute effect.

${ }^{2}$ Questionnaires were sent 6 weeks after last contact, either test or invitation.

${ }^{3}$ Unclear allocation concealment.

${ }^{4}$ No information regarding blinding.

${ }^{5}$ Quality rating is for a single study, thus imprecision and publication bias criteria were rated as "no" and "unlikely"

${ }^{6}$ Questionnaires given to participants after initial test or non-attendance (screening group) and to a sub-group of controls; data for screening attenders included in analysis only if questionnaire completed/returned before results of test received.

${ }^{7} \mathrm{~A}$ non-randomized sample of screening practices was used.

${ }^{8}$ Large loss to follow up (for the 3-6 and 12-15 month follow-up period.

reduction in the incidence of T2DM with the deployment of the FINDRISC and educational interventions, or FINDRISC in addition to repeat primary care consultation [26].

FINDRISC is a validated and effective method to identify risk ofT2DM, particularly in persons age 45-64. It considers important variables such as age; body mass index (BMI); waist circumference; physical activity; diet; antihypertensive medications; history of elevated glucose; and family history of diabetes (Table 9) [28]. The optimal cut point for detecting unknown diabetes was a FINDRISC score of greater or equal 15, yielding a sensitivity of $81.1 \%$ and specificity of $59.8 \%$. The AUROC curve for detecting unknown diabetes was 0.724 (95\% CI: 0.699, 0.770) [27].

\section{Screening Risk Assessment Tools and Questionnaires - Valid for Canada}

An 'accepted for publication' paper was located discussing the initial validation of the CANRISK tool [29]. The CANRISK was adapted from FINDRISC to account for 
Table 7. AMSTAR Criteria Applied Reviews

\begin{tabular}{|l|c|c|}
\hline & $\begin{array}{c}\text { Noble } \\
{[\mathbf{2 3}]}\end{array}$ & $\begin{array}{c}\text { WHO } \\
{[\mathbf{3 0}]}\end{array}$ \\
\hline \hline 'A priori' design & $\mathrm{Y}$ & $\mathrm{Y}$ \\
\hline Duplicate study selection and Data extraction & $\mathrm{Y}$ & $\mathrm{Y}$ \\
\hline Comprehensive literature search & $\mathrm{Y}$ & $\mathrm{Y}$ \\
\hline Status of publication use as an inclusion criterion & $\mathrm{Y}$ & $\mathrm{Y}$ \\
\hline List of included/excluded studies & $\mathrm{Y}$ & $\mathrm{Y}$ \\
\hline Characteristics of individual studies (aggregate) & $\mathrm{Y}$ & $\mathrm{Y}$ \\
\hline $\begin{array}{l}\text { Scientific quality of the included studies assessed } \\
\text { and documented }\end{array}$ & $\mathrm{Y}$ & $\mathrm{Y}$ \\
\hline $\begin{array}{l}\text { Scientific quality of the included studies used } \\
\text { appropriately in formatting conclusions }\end{array}$ & $\mathrm{Y}$ & $\mathrm{Y}$ \\
\hline Appropriate methods to combine studies & $\mathrm{Y}$ & $\mathrm{Y}$ \\
\hline Publication bias charted & $\mathrm{N}$ & $\mathrm{N}$ \\
\hline Conflict of interest stated & $\mathrm{Y}$ & $\mathrm{Y}$ \\
\hline Legend: Y= Yes; N=No. & & \\
\hline
\end{tabular}

the diverse ethnic composition of the Canadian population. It was studied in a cross-sectional study for the detection of diabetes and pre-diabetes. The variables added were ethnicity, sex, education and macrosomia (Table 9). Selected screening thresholds in the paper version are reported as; 21 slightly elevated, 29 moderate, 32 balanced, 33 high and 43 very high. The balanced score has a sensitivity of $70 \%$, specificity of $67 \%$, PPV of $35 \%$ and NPV of $90 \%$ (Table 10) [29].

\section{Screening for T2DM - Yield of Tests}

One high quality review was found that examined the most accurate and reliable tests to diagnose T2DM to patient outcomes [30]. Their analysis concluded that an A1C of $\geq 6.5 \%$ had a Positive Predictive Value (PPV) of $15.9 \%$, a Negative Predictive Value (PNV) of $97 \%$, sensitivity of $7.9 \%$ and specificity of $97 \%$ for the 10 year incidence of diabetes related retinopathy [30]. Graded as moderate quality evidence, the report recommended that the A1C test could be used as a diagnostic test and $6.5 \%$ is recommended as the cut point for diagnosing diabetes [30].

Considering the quality of this review, an additional review for evidence for the effective tests for diagnosing diabetes was completed, locating 12 papers that compared A1C with FPG for the detection of diabetes [31-41]. However, only four papers provided information on sensitivity, specificity, PPV/NPV and AUROC measures of $\mathrm{A} 1 \mathrm{C} \geq 6.5 \%$ detectingT2DM. Those studies report a range of sensitivity 24-56.9; specificity 98.4-99; PPV 50-84; PNV 96.6-98.8 and AUROC. 078-892 [33, 37, 39, 42].

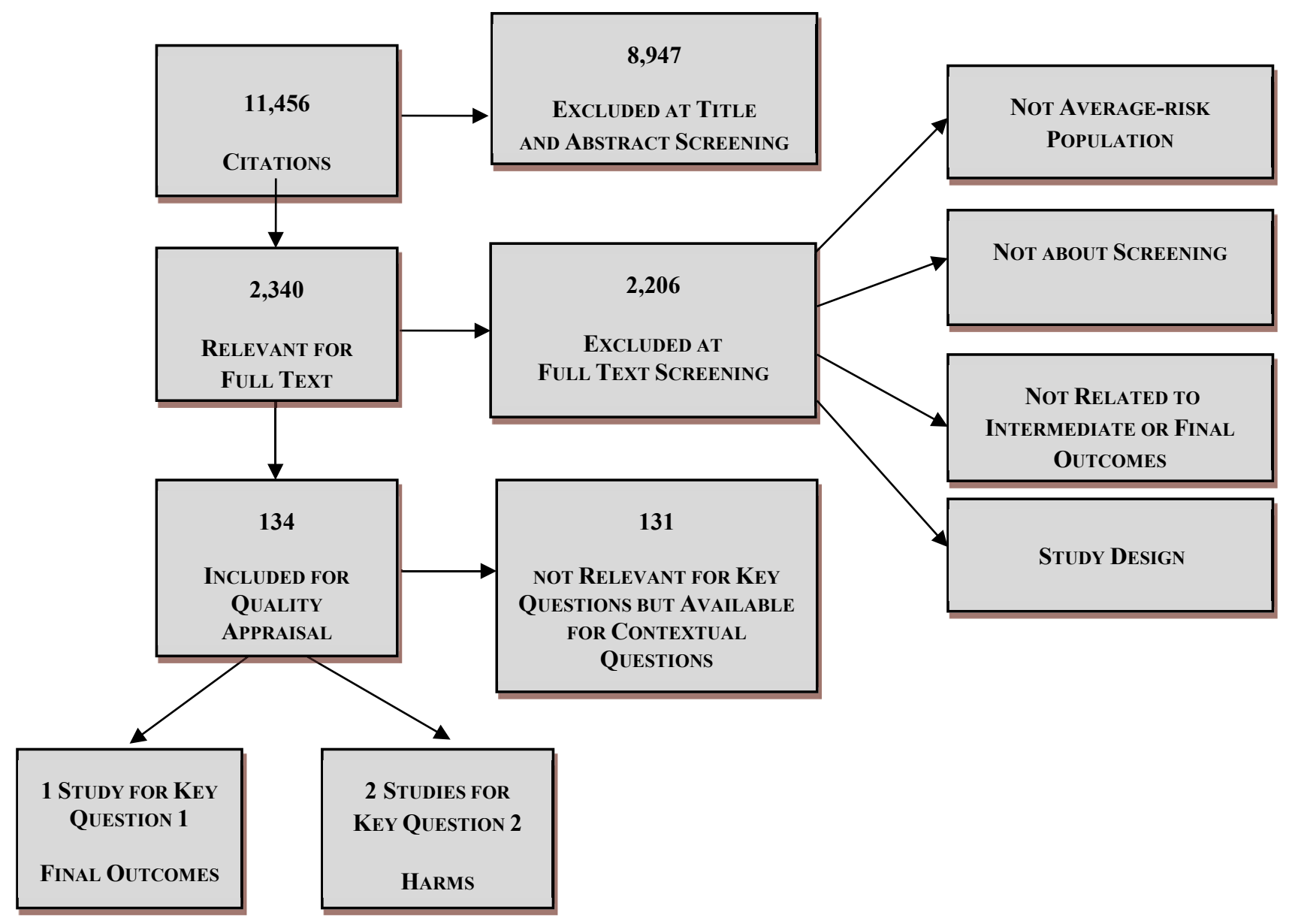

Fig. (1). Search results for key questions. 
Table 8. Components of Risk Assessment Tools

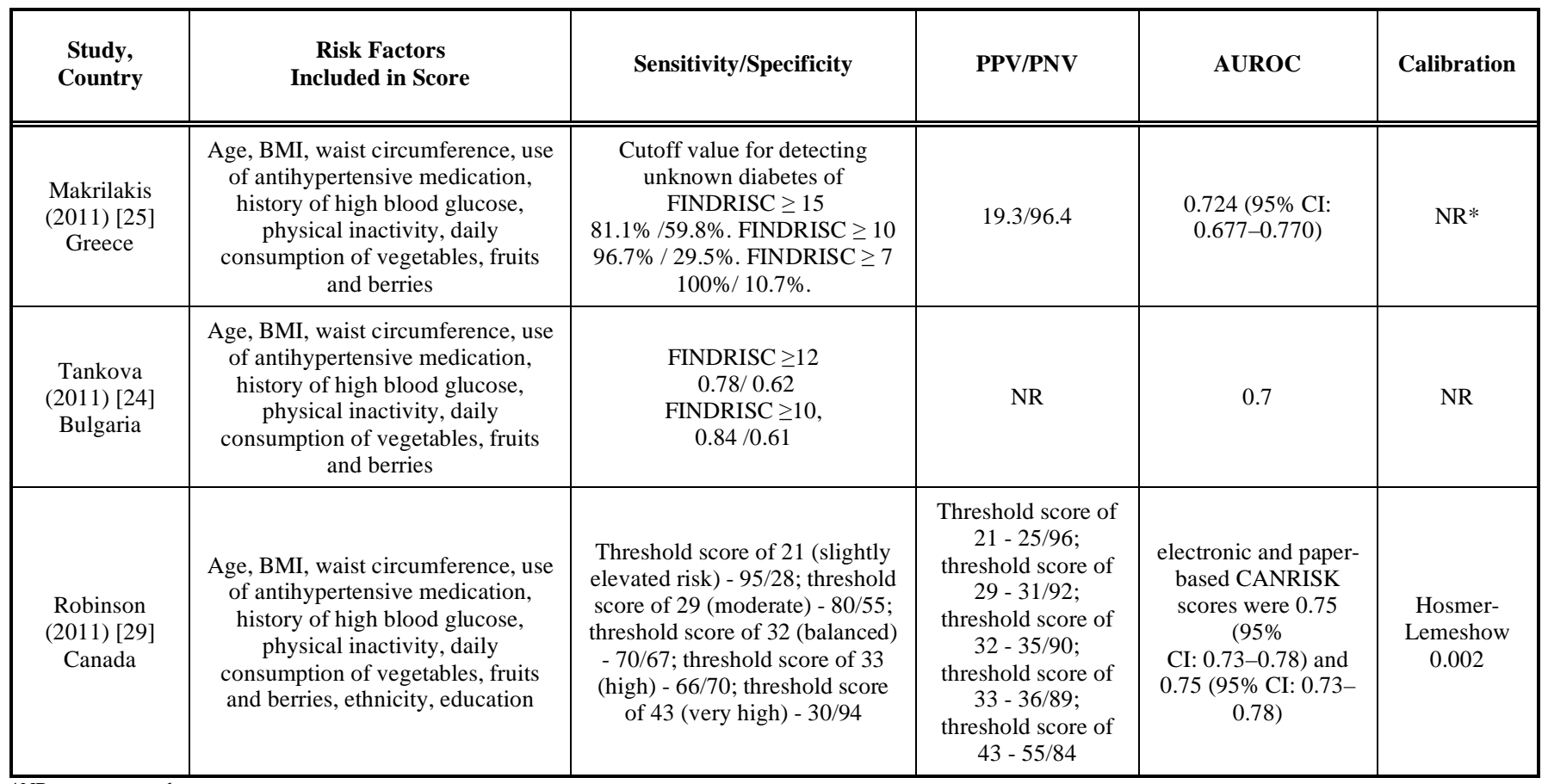

*NR - not reported.

Table 9. A1C and Prevalent Microvascular Complications-Study Characteristics [30]

\begin{tabular}{|c|c|c|c|c|c|c|c|c|}
\hline $\begin{array}{l}\text { Author, Year } \\
\text { and Country }\end{array}$ & $\begin{array}{c}\text { Subject no } \\
\& \text { Gender } \\
(\mathbf{M} / \mathbf{F})\end{array}$ & $\begin{array}{l}\text { Age } \\
\text { (Yrs) }\end{array}$ & $\begin{array}{l}\text { Prevalence of } \\
\text { Diabetes (\%) }\end{array}$ & Inclusion/Exclusion Criteria & A1C Test Method & $\begin{array}{l}\text { Glucose } \\
\text { method }\end{array}$ & $\begin{array}{l}\text { Diabetes } \\
\text { Diag. } \\
\text { criteria }\end{array}$ & $\begin{array}{l}\text { Blood } \\
\text { Sample }\end{array}$ \\
\hline $\begin{array}{l}\text { Expert } \\
\text { Committee } \\
\text { (1997), US }\end{array}$ & $\begin{array}{c}2,821 \\
\text { NR }\end{array}$ & $40-74$ & NR & NR & NR & NR & NR & NR \\
\hline $\begin{array}{l}\text { Miyazaki et al. } \\
\text { (2004), Japan }\end{array}$ & 1,637 & $40-79$ & $\begin{array}{c}21-23 \text { depending } \\
\text { on measurement } \\
(21 \text { for } 2-\mathrm{h} \text { PG } \geq \\
11.1 \mathrm{mmol} / \mathrm{L})\end{array}$ & $\begin{array}{l}\text { Age } 40-79 \text { years, not } \\
\text { receiving insulin treatment } \\
\text { (note: includes people } \\
\text { receiving oral anti- } \\
\text { hyperglycaemic treatment) }\end{array}$ & HPLC & $\begin{array}{l}\text { Glucose } \\
\text { oxidase }\end{array}$ & $\begin{array}{l}\text { WHO } \\
1999\end{array}$ & $\begin{array}{l}\text { Venous } \\
\text { plasma }\end{array}$ \\
\hline $\begin{array}{l}\text { Tapp et al. } \\
\text { (2006), } \\
\text { Australia }\end{array}$ & $\begin{array}{c}2,476 \\
1,114 / 1,362\end{array}$ & $\begin{array}{c}\text { Mean: } \\
59\end{array}$ & 34.5 & Age $\geq 25$ years & $\begin{array}{l}\text { Boronate affinity HPLC (Bio- } \\
\text { Rad Variant Haemoglobin } \\
\text { Testing System) CV: }<2 \%\end{array}$ & $\begin{array}{l}\text { Olympus } \\
\text { AU600 } \\
\text { analyser }\end{array}$ & $\begin{array}{l}\text { WHO } \\
1999\end{array}$ & $\begin{array}{l}\text { Venous } \\
\text { plasma }\end{array}$ \\
\hline
\end{tabular}

2-h PG = 2 hour plasma glucose; ADA = American Diabetes Association; BMI = body mass index; CV = coefficient of variation; HPLC = high-performance liquid chromatography; $\mathrm{NR}=$ not reported; $\mathrm{WHO}=$ World Health Organization. 
Table 9. (Cont'd): A1C, FPG and 2-h PG Cut-Points Associated with Prevalent Microvascular Complications [30]

\begin{tabular}{|c|c|c|c|c|c|c|c|c|c|c|c|c|c|}
\hline \multirow[b]{2}{*}{ Study } & \multirow[b]{2}{*}{ Complication } & \multicolumn{4}{|c|}{ HbA1c } & \multicolumn{4}{|c|}{ FPG } & \multicolumn{4}{|c|}{ 2-h PG } \\
\hline & & $\begin{array}{c}\text { Optimum } \\
\text { Cut-Point } \\
(\%)\end{array}$ & AROC & $\begin{array}{c}\text { Sens. } \\
(\%)\end{array}$ & $\begin{array}{l}\text { Spec. } \\
(\%)\end{array}$ & $\begin{array}{l}\text { Optimum } \\
\text { Cut-Point } \\
(\mathrm{mmol} / \mathrm{L})\end{array}$ & AROC & $\begin{array}{c}\text { Sens. } \\
(\%)\end{array}$ & $\begin{array}{l}\text { Spec. } \\
(\%)\end{array}$ & $\begin{array}{l}\text { Optimum } \\
\text { Cut-Point } \\
(\mathrm{mmol} / \mathrm{L})\end{array}$ & AROC & $\begin{array}{l}\text { Sens. } \\
(\%)\end{array}$ & $\begin{array}{c}\text { Spec. } \\
(\%)\end{array}$ \\
\hline \multirow{2}{*}{$\begin{array}{c}\text { Colagiuri et al. } \\
\text { (in press, Diabetes Care) }\end{array}$} & $\begin{array}{c}\text { Retinopathy } \\
\text { (ROC curve analysis) }\end{array}$ & $\geq 6.3$ & 0.90 & 86 & 6 & $\geq 6.5$ & 0.87 & 82 & 81 & $\geq 12.4$ & 0.89 & 83 & 83 \\
\hline & $\begin{array}{l}\text { Retinopathy } \\
\text { (visual inspection of } \\
\text { decile distribution) }\end{array}$ & $6.4-6.8$ & NR & NR & NR & $6.4-6.8$ & NR & NR & NR & $9.8-10.6$ & NR & NR & NR \\
\hline \multirow{2}{*}{ Engelgau et al. (1997) } & $\begin{array}{l}\text { Bi-modal: } \\
\text { - Entire pop. }\end{array}$ & $\geq 6.7$ & NR & 68 & 100 & $\geq 7.2$ & NR & 84 & 100 & $\geq 11.5$ & NR & 90 & 100 \\
\hline & $\begin{array}{l}\text { Retinopathy\#: } \\
\text { - Entire population }\end{array}$ & $\geq 7.6$ & 0.82 & NR & NR & $\geq 6.6$ & $0.85^{*}$ & NR & NR & $\geq 14.4$ & $0.86^{*}$ & NR & NR \\
\hline Expert Committee, (1997) & Retinopathy & $\geq 6.2$ & NR & NR & NR & $\geq 6.7$ & NR & NR & NR & $\geq 10.8$ & NR & NR & NR \\
\hline Ito et al. (2000a) & Retinopathy & $\geq 7.3$ & NR & NR & NR & $\geq 7.0$ & NR & NR & NR & $\geq 11.0$ & NR & NR & NR \\
\hline \multirow{3}{*}{ McCance et al. (1994) } & Retinopathy & $\geq 7.0$ & NR & 78 & 85 & $\geq 7.2$ & NR & 81 & 80 & $\geq 13.0$ & NR & 88 & 81 \\
\hline & WHO equivalent & $\geq 6.1$ & NR & 81 & 77 & $\geq 6.8$ & NR & 81 & 77 & $\geq 11.1$ & NR & 88 & 76 \\
\hline & $\begin{array}{l}\text { ROC curve } \\
\text { analysis }\end{array}$ & $\geq 5.7$ & 0.95 & 87 & 90 & $\geq 6.4$ & 0.96 & 87 & 87 & $\geq 11.1$ & 0.90 & 87 & 90 \\
\hline Miyazaki et al. (2004) & Retinopathy & $\geq 5.8$ & NR & NR & NR & $\geq 6.5$ & NR & NR & NR & $\geq 11.0$ & NR & NR & NR \\
\hline \multirow{4}{*}{ Tapp et al. (2006) } & Retinopathy & $\geq 6.1$ & NR & NR & NR & $\geq 7.1$ & NR & NR & NR & $\geq 13.1$ & NR & NR & NR \\
\hline & Microalbuminuria & $\geq 6.1$ & NR & NR & NR & $\geq 7.2$ & NR & NR & NR & NR & NR & NR & NR \\
\hline & Retinopathy§ & $\geq 6.0$ & NR & NR & NR & $\geq 8.5$ & NR & NR & NR & NR & NR & NR & NR \\
\hline & Microalbuminuria & NIL & - & - & - & NIL & - & - & - & NR & NR & NR & NR \\
\hline
\end{tabular}

*Significantly different from HbA1c $(\mathrm{p}<0.01)$; \# Median decile value; $\S$ By change point analysis. 2-h PG = 2 hour plasma glucose; AROC = Area under the receiveroperator characteristic curve; FPG $=$ fasting plasma glucose; NR $=$ Not reported; ROC $=$ receiver operator characteristic; WHO $=$ World Health Organization.

Table 9. (Cont'd): A1c and Incident Microvascular Complications - Study Characteristics [30]

\begin{tabular}{|c|c|c|c|c|c|c|c|c|c|}
\hline $\begin{array}{c}\text { Author, Year and } \\
\text { Country }\end{array}$ & $\begin{array}{l}\text { Subject No } \\
\text { \& Gender } \\
\text { (M/F) }\end{array}$ & $\begin{array}{l}\text { Age } \\
\text { (Yrs) }\end{array}$ & $\begin{array}{l}\text { Follow- } \\
\text { Up } \\
\text { (Years) }\end{array}$ & $\begin{array}{l}\text { Incidence of } \\
\text { Diabetes (\%) }\end{array}$ & $\begin{array}{c}\text { Inclusion/ } \\
\text { Exclusion } \\
\text { Criteria }\end{array}$ & A1C Test Method & $\begin{array}{l}\text { Glucose } \\
\text { Method }\end{array}$ & $\begin{array}{c}\text { Diabetes } \\
\text { Diagnostic } \\
\text { Criteria }\end{array}$ & $\begin{array}{l}\text { Blood } \\
\text { Sample }\end{array}$ \\
\hline $\begin{array}{c}\text { Massin et al. } \\
\text { (in press, Archives } \\
\text { of Ophthalmol), } \\
\text { France }\end{array}$ & $\begin{array}{c}700 \\
504 / 196\end{array}$ & $30-65$ & 10 & $\begin{array}{c}\text { NR } \\
\text { Retinopathy: } \\
6.3\end{array}$ & $\begin{array}{c}\text { Aged } 30-65 \text { years. } \\
\text { Excluded if } \\
\text { uninterpretable } \\
\text { retinal } \\
\text { photographs }\end{array}$ & $\begin{array}{c}\text { HPLC } \\
\text { (Hitachi/Merck- } \\
\text { VWR) or } \\
\text { DCA 2000 automated } \\
\text { immunoassay system } \\
\text { (Bayer Diagnostics) }\end{array}$ & $\begin{array}{l}\text { Glucose } \\
\text { oxidase }\end{array}$ & NR & $\begin{array}{l}\text { Venous } \\
\text { plasma }\end{array}$ \\
\hline $\begin{array}{l}\text { Van Leiden } \\
\text { et al. (2003), } \\
\text { Netherlands }\end{array}$ & $\begin{array}{c}233 \\
124 / 109\end{array}$ & $50-74$ & 9.4 & $\begin{array}{c}\text { NR } \\
\text { Retinopathy: } \\
11.6\end{array}$ & $\begin{array}{l}\text { Aged 50-74 years } \\
\text { from Hoorn, } \\
\text { Netherlands. }\end{array}$ & $\begin{array}{c}\text { HPLC (Modular } \\
\text { Diabetes Monitoring } \\
\text { system; Bio-Rad) } \\
\text { Normal range: } 4.3- \\
6.1 \%\end{array}$ & $\begin{array}{l}\text { Glucose } \\
\text { Dehydro- } \\
\text { genase }\end{array}$ & $\begin{array}{l}\text { WHO } \\
1999\end{array}$ & $\begin{array}{l}\text { Venous } \\
\text { plasma }\end{array}$ \\
\hline
\end{tabular}

HPLC = high-performance liquid chromatography; NR = not reported; WHO = World Health Organization.

\section{INTERPRETATION}

Since the publication of the 2005 CTFPHC and the 2008 USPSTF report for screening for T2DM recommendations, there has been one new cohort study publication to contribute to the discussion about the effectiveness of screening for T2DM [6,7]. Notably, the previous USPSTF also identified only observational studies and no randomized controlled trials for the effectiveness of screening forT2DM. The population-based study demonstrated that screening had a non-significant reduction on mortality; however, no new evidence was found regarding the effectiveness of screening for T2DM on intermediate outcomes, such as, incidence ofT2DM, differences in A1C levels, and frequency of diagnosis. Notably, the Anglo Danish-Dutch Study of Intensive Treatment in people with screen detected diabetes in primary care (ADDITION) study group focused screening in relatively a low prevalence population $(\sim 3 \%)$ and only the top quartile of the population at risk were asked to participate in the trial $[43,44]$. 
Table 10. GRADE Table for A1C and Incident Microvascular Complications [30]

\begin{tabular}{|c|c|c|c|c|c|c|c|c|c|c|}
\hline \multirow[b]{2}{*}{ Outcome } & \multirow[b]{2}{*}{ No. of Studies } & \multirow[b]{2}{*}{ Study Design } & \multicolumn{5}{|c|}{ Factors that may Decrease Quality of Evidence } & \multirow[b]{2}{*}{ Final Quality } & \multirow{2}{*}{$\begin{array}{c}\text { Effect } \\
\text { Per 1000 }^{1}\end{array}$} & \multirow[b]{2}{*}{ Importance } \\
\hline & & & Limits & Indirectness & Inconsistency & Imprecision & $\begin{array}{c}\text { Reporting } \\
\text { Bias }\end{array}$ & & & \\
\hline $\begin{array}{l}\text { True positives } \\
\text { (patients with } \\
\text { incident } \\
\text { complications) }\end{array}$ & $\begin{array}{l}1 \text { study } \\
\text { (700 } \\
\text { patients) }\end{array}$ & Observational & None & None & $\mathrm{N} / \mathrm{A}^{3}$ & $\begin{array}{c}\text { Not } \\
\text { assessable }^{2}\end{array}$ & Unlikely & $\begin{array}{c}\oplus \oplus \mathrm{OO} \\
\text { low }\end{array}$ & $\begin{array}{l}\text { Prev 80\%: } 128 \\
\text { Prev 40\%: } 64 \\
\text { Prev 10\%: } 16\end{array}$ & IMPORTANT \\
\hline $\begin{array}{l}\text { True negatives } \\
\text { (patients } \\
\text { without } \\
\text { incident } \\
\text { complications) }\end{array}$ & $\begin{array}{c}1(700 \\
\text { patients })\end{array}$ & Observational & None & None & $\mathrm{N} / \mathrm{A}^{3}$ & $\begin{array}{c}\text { Not } \\
\text { assessable }^{2}\end{array}$ & Unlikely & $\begin{array}{c}\oplus \oplus \mathrm{OO} \\
\text { low }\end{array}$ & $\begin{array}{l}\text { Prev 80\%: } 194 \\
\text { Prev 40\%: } 582 \\
\text { Prev 10\%: } 873\end{array}$ & IMPORTANT \\
\hline $\begin{array}{l}\text { False positives } \\
\text { (patients } \\
\text { incorrectly } \\
\text { classified as } \\
\text { having incident } \\
\text { complications) }\end{array}$ & $\begin{array}{c}1(700 \\
\text { patients })\end{array}$ & Observational & None & None & $\mathrm{N} / \mathrm{A}^{3}$ & $\begin{array}{c}\text { Not } \\
\text { assessable }^{2}\end{array}$ & Unlikely & $\begin{array}{c}\oplus \oplus \mathrm{OO} \\
\text { low }\end{array}$ & $\begin{array}{c}\text { Prev 80\%: } 6 \\
\text { Prev 40\%: } 18 \\
\text { Prev 10\%: } 27\end{array}$ & IMPORTANT \\
\hline $\begin{array}{l}\text { False negatives } \\
\text { (patients } \\
\text { incorrectly } \\
\text { classified } \\
\text { as not having } \\
\text { incident } \\
\text { complications) }\end{array}$ & $\begin{array}{c}1(700 \\
\text { patients) }\end{array}$ & Observational & None & None & $N / A^{3}$ & $\begin{array}{c}\text { Not } \\
\text { assessable }^{2}\end{array}$ & Unlikely & $\begin{array}{c}\oplus \oplus \mathrm{OO} \\
\text { low }\end{array}$ & $\begin{array}{c}\text { Prev 80\%: } 672 \\
\text { Prev 40\%: } 336 \\
\text { Prev 10\%: } 84\end{array}$ & IMPORTANT \\
\hline Inconclusive $^{4}$ & $\begin{array}{l}1 \text { study } \\
\text { (233 } \\
\text { patients) }\end{array}$ & Observational & - & - & - & - & - & - & - & IMPORTANT \\
\hline Cost & $\begin{array}{l}\text { Not } \\
\text { reported }\end{array}$ & - & - & - & - & - & - & - & - & NOT RELEVANT \\
\hline
\end{tabular}

${ }^{1}$ Based on combined sensitivity of $16 \%$ and specificity of $97 \% ;{ }^{2}$ Imprecision could not be assessed as confidence intervals were not reported; ${ }^{3}$ Inconsitency is not applicable with data from only one study; ${ }^{4}$ This study did not report information on sensitivity and specificity of HbA1C for predicting incident microvascular complications,

Cost effectiveness studies varied in their conclusions, particularly due to differences in modeling techniques and in assumptions relating to screening methods, glucose control requirements and future treatment protocols. The harms associated with screening for T2DM were minimal, with little effect on anxiety levels, self-rated health status and quality of life. Risk assessment tools with internal and external validity can be effective at identifying individuals who are at high risk of being diagnosed with diabetes. Screening with tests A1C, FPG or OGTT provide similar diagnostic outcomes, however A1C is easiest to administer and is cost effective.

This review is not without limitations. The search was limited to only those databases searched in the USPSTF review; therefore EMBASE was excluded. We found no new trials that examined the effectiveness of screening forT2DM. The studies found for the harms (anxiety) of screening were too heterogeneous for a meta-analysis.

Finally, the CTFPHC recommendations that were generated from this review include the screening of individuals deemed to be at high risk (1/3 or $33 \%$ risk of developing T2DM in 10 years) and very high risk $(1 / 2$ or $50 \%$ risk of developing T2DM in 10 years), as determined with a validated risk calculator, such as the FINDRISC or CANRISK [45]. Specifically, for adults that were at high risk of diabetes, a recommendation to screen every 3-5 years with an $\mathrm{A} 1 \mathrm{C}$ test was made and for adults at very high risk, a recommendation of screening annually with an A1C test was stated. Unlike the ADA that states screening should commence at a certain age (45 years) [9], the CTFPHC recommendations relying on calculated risk for T2DM, which considers variables such as age, obesity, history of elevated glucose, history of hypertension, family history of diabetes, limited activity levels and fruit and vegetable intake [45].

The effectiveness of a T2DM screening intervention has not been adequately tested to date in a randomized controlled trial, particularly in individuals at high risk for diabetes and its complications. Screening interventions may include the tests (questionnaire, blood test) or the process (stepwise approach versus an alternative approach). Further research is required to determine the effect of screening forT2DM, the best approach to screening (detection, minimizes harm and is cost effective) and the best treatment once prediabetes or T2DM is diagnosed.

\section{CONFLICT OF INTEREST}

The authors confirm that this article content has no conflict of interest.

\section{ACKNOWLEDGEMENTS}

Other MERSC contributors included Mahbubel Haq, Sohel Nazmul, Sharon Peck-Reid, Maureen Rice. Canadian Task Force on Preventive Health Care members who contributed to the protocol development and/or discussion of findings includes the Diabetes Guideline Working Group: 
Kevin Pottie, N. Bell, P. Brauer, J. Dickinson, G. Lewin, P. Parkin.

Funding for this review is from the Canadian Institutes of Health Research. The views expressed herein are the opinions of the authors and do not necessarily represent the views of the Canadian Institutes of Health Research.

\section{REFERENCES}

[1] Public Health Agency of Canada. Report from the National Diabetes Surveillance System: Diabetes in Canada, 2009. Available at: http://www.phac-aspc.gc.ca/ccdpc-cpcmc/ndss-snsd/english/ind ex-eng.php

[2] Public Health Agency of Canada. Diabetes in Canada: Facts and Figures from a public health perspective. Ottawa, Canada: Public Health Agency of Canada 2011.

[3] Klein R, Klein BE, Moss SE, Davis MD, DeMets DL.The Wisconsin epidemiologic study of diabetic retinopathy. III. Prevalence and risk of diabetic retinopathy when age at diagnosis is 30 or more years. Arch Ophthalmol 1984; 104: 527-32.

[4] UK Prospective Diabetes Study (UKPDS) Group. Intensive bloodglucose control with sulphonylureas or insulin compared with conventional treatment and risk of complications in patients with type 2 diabetes (UKPDS 33). Lancet 1998; 352: 837-53.

[5] UK Prospective Diabetes Study (UKPDS) Group: Tight blood pressure control and risk of macrovascular and microvascular complications in type 2 diabetes: UKPDS 38. BMJ 1998; 317: 70313.

[6] Feig DS, Palda VA, Lipscombe L. Screening for type 2 diabetes mellitus to prevent vascular complications: updated recommendations from the Canadian Task Force on Preventive Health Care. CMAJ 2005; 172: 177-80.

[7] Norris SL, Kansagara D, Bougatsos C, Fu R, U.S.Preventive Services Task Force. Screening adults for type 2 diabetes: a review of the evidence for the U.S. Preventive Services Task Force. Ann Intern Med 2008; 148: 855-68.

[8] World Health Organization. Screening for Type 2 Diabetes. Geneva, Switzerland: World Health Organization; 2003. Available at: http://www.who.int/diabetes/publications/en/screening_mnc03.p df

[9] American Diabetes Association. Standards of Medical Care in Diabetes - 2010. Diabetes Care 2010; 36: S11-S66.

[10] GRADEpro. [Computer program]. Version 3.2 for Windows [computer program]. 2008.

[11] Guyatt GH, Oxman AD, Vist GE, et al. GRADE: an emerging consensus on rating quality of evidence and strength of recommendations. BMJ 2008; 336: 924-6.

[12] GRADE working group. 2000. Available at: http://www.gradework inggroup.org/

[13] Shea BJ, Grimshaw JM, Wells GA, et al. Development of AMSTAR: a measurement tool to assess the methodological quality of systematic reviews. BMC Med Res Methodol 2007; 7: 10-6.

[14] Canadian Task Force on Preventive Health Care. Canadian Task Force on Preventive Health Care: Procedure Manual. 2011.

[15] Drummond MF, Sculpher MJ, Torrance GW. Methods for the economic evaluation of health care programmes. $2^{\text {nd }}$ ed. Glasgow, UK: Oxford Medical Press 1997.

[16] ERSC. Screening for Type 2 diabetes: systematic review 2012. Available at: http://canadiantaskforce.ca/wpcontent/uploads/2012/1 0/Diabetes_Screening_06182012FINAL.pdf

[17] Simmons RK, Rahman M, Jakes RW, et al. Effect of population screening for type 2 diabetes on mortality: long-term follow-up of the Ely cohort. Diabetologia 2011; 54: 312-9.

[18] Eborall HC, Griffin SJ, Prevost AT, Kinmonth AL, French DP, Sutton S. Psychological impact of screening for type 2 diabetes: controlled trial and comparative study embedded in the ADDITION (Cambridge) randomised controlled trial. BMJ 2007; 335: 486.

[19] Park P, Simmons RK, Prevost AT, Griffin SJ. Screening for type 2 diabetes is feasible, acceptable, but associated with increased shortterm anxiety: a randomised controlled trial in British general practice. BMC Public Health 2008; 8: 350.
[20] U.S.Preventive Services Task Force. Screening for type 2 diabetes mellitus in adults: U.S. Preventive Services Task Force recommendation statement. Ann Intern Med 2008; 148: 846-54.

[21] Waugh N, Scotland G, McNamee P, et al. Screening for type 2 diabetes: literature review and economic modelling. Health Technol Assess 2007; 11: 1-125.

[22] Kahn R, Alperin P, Eddy D, et al. Age at initiation and frequency of screening to detect type 2 diabetes: a cost-effectiveness analysis. Lancet 2010; 375: 1365-74.

[23] Noble D, Mathur R, Dent T, Meads C, Greenhalgh T. Risk models and scores for type 2 diabetes: systematic review. BMJ 2011; 343: d7163.

[24] Tankova T, Chakarova N, Atanassova I, Dakovska L. Evaluation of the Finnish Diabetes Risk Score as a screening tool for impaired fasting glucose, impaired glucose tolerance and undetected diabetes. Diabetes Res Clin Pract 2011; 92: 46-52.

[25] Makrilakis K, Liatis S, Grammatikou S, et al. Validation of the Finnish diabetes risk score (FINDRISC) questionnaire for screening for undiagnosed type 2 diabetes, dysglycaemia and the metabolic syndrome in Greece. Diabetes Metab 2011; 37: 144-51.

[26] Lindstrom J, Absetz P, Hemio K, Peltomaki P, Peltonen M. Reducing the risk of type 2 diabetes with nutrition and physical activity - efficacy and implementation of lifestyle interventions in Finland. Public Health Nutr 2010; 13: 993-9.

[27] Lindstrom J, Tuomilehto J. The diabetes risk score: a practical tool to predict type 2 diabetes risk. Diabetes Care 2003; 26: 725-31.

[28] Lindstrom J, Peltonen M, Eriksson JG, et al. Determinants for the effectiveness of lifestyle intervention in the Finnish Diabetes Prevention Study. Diabetes Care 2008; 31: 857-62.

[29] Robinson CA, Agarwal G, Nerenberg K. Validating the CANRISK prognostic model for assessing diabetes risk in Canada's multiethnic population. Chronic Dis Inj Can. 2011; 32: 19-31.

[30] World Health Organization. HbA1c in the diagnosis of type 2 diabetes: a systematic review. Geneva, Switzerland: World Health Organization; 2011 Available at: http://www.who.int/entity/diabet es/publications/sys_rev_hbalc_web.pdf

[31] Pajunen P, Peltonen M, Eriksson JG, et al. $\mathrm{HbA}(1 \mathrm{c})$ in diagnosing and predicting Type 2 diabetes in impaired glucose tolerance: the Finnish Diabetes Prevention Study. Diabet Med 2011; 28: 36-42.

[32] Abdul-Ghani MA, Abdul-Ghani T, Muller G, et al. Role of glycated hemoglobin in the prediction of future risk of T2DM. J Clin Endocrinol Metab 2011 96: 2596-600.

[33] Peter A, Fritsche A, Stefan N, Heni M, Haring HU, and Schleicher E. Diagnostic value of hemoglobin A1c for type 2 diabetes mellitus in a population at risk. Exp Clin Endocrinol Diabetes 2011; 119: 234-7.

[34] Chamnan P, Simmons RK, Forouhi NG, et al. Incidence of type 2 diabetes using proposed $\mathrm{HbAlc}$ diagnostic criteria in the european prospective investigation of cancer-norfolk cohort: implications for preventive strategies. Diabetes Care 2011; 34: 950-6.

[35] Valdes S, Botas P, Delgado E, Alvarez F, Diaz-Cadorniga F. $\mathrm{HbA}(1 \mathrm{c})$ in the prediction of type 2 diabetes compared with fasting and 2-h post-challenge plasma glucose: The Asturias study (19982005). Diabetes Metab 2011; 37: 27-32.

[36] Wang W, Lee ET, Howard BV, Fabsitz RR, Devereux RB, Welty TK. Fasting plasma glucose and hemoglobin A1c in identifying and predicting diabetes: the strong heart study. Diabetes Care 2011; 34: 363-8.

[37] Lipska KJ, De RN, Van Ness PH, et al. Identifying dysglycemic states in older adults: implications of the emerging use of hemoglobin A1c. J Clin Endocrinol Metab 2010; 95: 5289-95.

[38] Lorenzo C, Wagenknecht LE, Hanley AJ, et al. A1C between 5.7 and $6.4 \%$ as a marker for identifying pre-diabetes, insulin sensitivity and secretion, and cardiovascular risk factors: the Insulin Resistance Atherosclerosis Study (IRAS). Diabetes Care 2010; 33: 2104-9.

[39] van't RE, Alssema M, Rijkelijkhuizen JM, Kostense PJ, Nijpels G, Dekker JM. Relationship between A1C and glucose levels in the general Dutch population: the new Hoorn study. Diabetes Care 2010; 33: 61-6.

[40] Carson AP, Reynolds K, Fonseca VA, Muntner P. Comparison of $\mathrm{A} 1 \mathrm{C}$ and fasting glucose criteria to diagnose diabetes among U.S. adults. Diabetes Care 2010; 33: 95-7.

[41] Motta M, Bennati E, Cardillo E, Ferlito L, Malaguarnera M. The value of glycosylated hemoglobin ( $\mathrm{HbA} 1 \mathrm{c})$ as a predictive risk 
factor in the diagnosis of diabetes mellitus (DM) in the elderly. Arch Gerontol Geriatr 2010; 50: 60-4.

[42] Selvin E, Steffes MW, Gregg E, Brancati FL, Coresh J. Performance of $\mathrm{A} 1 \mathrm{C}$ for the classification and prediction of diabetes. Diabetes Care 2011; 34: 84-9.

[43] Lauritzen T, Griffin S, Borch-Johnsen K, Wareham NJ, Wolffenbuttel BHR, Rutten G. The ADDITION study: proposed trail of the cost-effectiveness of an intensive multifactorial intervention on morbiidity and mortality amoung people with Type 2 diabetes dected by screening. Int J Obesity 2000; Suppl 3: S6-S11.

[44] Simmons RK, Echouffo-Tcheugui JB, Sharp SJ, et al. Screening for type 2 diabetes and population mortality over 10 years (ADDITION -Cambridge): a cluster randomized controlled trial. Lancet 2012; 380(9855): 1741-8.

[45] Canadian Task Force on Preventive Health Care. Recommendations for screening for type 2 diabetes in adults. CMAJ 2012; 184: 1687-96.

Received: January 13, 2013

Revised: February 20, 2013

Accepted: February 28, 2012

(C) Sherifali et al.; Licensee Bentham Open.

This is an open access article licensed under the terms of the Creative Commons Attribution Non-Commercial License (http://creativecommons.org/licenses/ by-nc/3.0/) which permits unrestricted, non-commercial use, distribution and reproduction in any medium, provided the work is properly cited. 